\title{
PEMODELAN DOUBLE SEASONAL AUTOREGRESSIVE INTEGRATED MOVING AVERAGE PADA PERAMALAN PENGGUNAAN BEBAN LISTRIK
}

\author{
Suaibah, Shantika Martha, Dadan Kusnandar
}

\begin{abstract}
INTISARI
Beban listrik adalah segala sesuatu yang ditanggung oleh pembangkit listrik. Perkiraan tenaga listrik yang digunakan oleh masyarakat dapat dilakukan dengan menggunakan beberapa metode peramalan. Data yang digunakan dalam penelitian ini adalah data penggunaan beban listrik di Kabupaten Natuna yang memiliki dua pola musiman berbeda, sehingga metode yang sesuai dalam penelitian ini adalah metode Double Seasonal Autoregressive Integrated Moving Average (DSARIMA). Model DSARIMA merupakan model ARIMA yang mengandung dua pola musiman. Data beban listrik diperoleh dari PT. PLN Persero dalam skala waktu per jam yang diamati selama bulan Desember 2018. Tujuan dari penelitian ini adalah untuk menentukan model terbaik dalam meramalkan penggunaan beban listrik dan menganalisis hasil peramalan. Pemodelan diawali dengan mengidentifikasi data yang meliputi uji stasioneritas baik dalam rata-rata maupun varians. Selanjutnya menentukan orde berdasarkan plot ACF dan PACF. Kemudian melakukan estimasi dan uji signifikansi parameter model DSARIMA, dilanjutkan dengan melakukan cek diagnosa yang meliputi uji white noise dan uji distribusi normal. Pemilihan model terbaik dari beberapa model terpilih dilakukan dengan cara membandingkan nilai MAPE out sample. Hasil penelitian menunjukkan bahwa model terbaik yang dapat digunakan dalam meramalkan penggunaan beban listrik di Kabupaten Natuna adalah model ARIMA dua musiman dengan periode musiman per 24 jam dan per 168 jam, yang dapat ditulis sebagai model DSARIMA(2, 1,[ 24]) $(0,1,0)^{24}$ $(0,1,0)^{168}$ dengan nilai MAPE out sample sebesar $8,9 \%$.
\end{abstract}

Kata Kunci: Beban listrik, peramalan, DSARIMA, MAPE

\section{PENDAHULUAN}

Metode peramalan merupakan bagian penting dalam ilmu statistika. Peramalan merupakan suatu kegiatan untuk memperkirakan atau memprediksi suatu kejadian atau keadaan yang terjadi pada masa yang akan datang. Terdapat dua kategori metode peramalan yaitu metode kuantitatif dan metode kualitatif. Metode kuantitatif yaitu metode yang memasukan dan menguji variabel-variabel yang diduga mempengaruhi variabel terikat (dependen), sedangkan metode kualitatif merupakan metode yang memasukkan pendapat-pendapat atau hasil dugaan dalam model peramalan [1].

Beban listrik adalah segala sesuatu yang ditanggung oleh pembangkit listrik atau bisa disebut segala sesuatu yang membutuhkan tenaga listrik. Kebutuhan listrik bergantung pada pemakaian peralatan listrik yang digunakan oleh masyarakat, sehingga PLN wajib menyesuaikan kebutuhan listrik masyarakat dari waktu ke waktu [2]. Meningkatnya kebutuhan dan jumlah konsumen berbanding lurus dengan meningkatnya permintaan beban listrik dari waktu ke waktu. Jika permintaan lebih besar daripada persediaan maupun sebaliknya maka akan terjadi pemborosan listrik dan kegagalan sistem [3]. PLN bertugas untuk memperkirakan daya listrik yang dikonsumsi masyarakat tiap jam. Perkiraan ini dibuat berdasarkan atas data penggunaan beban listrik pada waktu sebelumnya. Perkiraan besarnya penggunaan beban listrik digunakan untuk mengoptimalkan penggunaan beban listrik di masyarakat, sehingga tidak akan terjadi pemborosan ataupun pemadaman listrik. Perkiraan beban listrik yang digunakan oleh masyarakat dapat dilakukan dengan menggunakan beberapa metode peramalan, salah satunya adalah Double Seasonal Autoregressive Integrated Moving Average (DSARIMA) [2]. Peramalan penggunaan beban listrik diperlukan untuk mengontrol maupun sebagai bahan pertimbangan dalam menjadwalkan pemeliharaan sistem tenaga listrik dalam upaya mengurangi masalah yang timbul akibat tidak seimbangnya permintaan dan persediaan. 
Model DSARIMA merupakan model ARIMA yang mengandung pola dua musiman. ARIMA merupakan salah satu metode statistik yang dapat digunakan untuk meramalkan suatu kejadian di masa depan berdasarkan data yang sudah lampau dan errornya. Salah satu syarat yang harus dipenuhi adalah data harus bersifat stasioner [4]. Oleh karena itu pada penelitian ini dilakukan pemodelan DSARIMA untuk diterapkan dalam peramalan penggunaan beban listrik di Kabupaten Natuna dalam skala waktu per jam yang diamati selama satu bulan yaitu bulan Desember 2018.

Langkah pertama analisis yang digunakan dalam penelitian ini adalah menghitung statistik deskriptif, yaitu berupa rata-rata, standar deviasi, nilai maksimum, dan nilai minimum. Analisis juga dilakukan dengan menggunakan plot deret waktu. Hal ini dilakukan untuk mengetahui pola dan karakteristik penggunaan beban listrik di Kabupaten Natuna. Langkah kedua membagi data menjadi in sample dan out sample.

Langkah ketiga membentuk model DSARIMA dengan cara mengidentifikasi data yang meliputi uji stasioneritas, baik dalam rata-rata maupun varians. Selanjutnya menentukan orde berdasarkan plot ACF (Autocorrelation Function) dan PACF (Parsial Autocorrelation Function). Melakukan estimasi dan uji signifikansi parameter model DSARIMA, kemudian cek diagnosa yang meliputi uji white noise dan uji distribusi normal. Untuk menguji white noise digunakan uji Ljung Box, sedangkan untuk menguji distribusi normal digunakan uji Kolmogorov-Smirnov. Pemilihan model terbaik dilakukan dengan cara membandingkan nilai MAPE out sample. Model terbaik adalah model yang memiliki MAPE out sample terkecil. Model akan digunakan dalam peramalan penggunaan beban listrik di Kabupaten Natuna.

\section{ANALISIS DERET WAKTU}

Pemodelan deret waktu sering ditemukan data dengan kondisi tidak stasioner terhadap rata-rata, sehingga diperlukan suatu cara untuk menstasionerkan data yaitu dengan cara differencing [5]. Secara umum, differencing orde ke- $d$ dapat dirumuskan sebagai berikut [6]:

$$
Z_{t}^{d}=(1-B)^{d} Z_{t},
$$

dengan $Z_{t}^{d}$ merupakan data pada waktu ke-t setelah differencing, $(1-B)^{d}$ merupakan differencing orde ke- $d$ dan $Z_{t}$ merupakan data pada waktu ke-t. Data musiman yang tidak stasioner terhadap ratarata juga dilakukan differencing musiman dengan menggunakan persamaan sebagai berikut [6]:

$$
Z_{t}^{D}=\left(1-B^{S}\right)^{D} Z_{t},
$$

dengan $S$ adalah periode per musiman dan $D$ adalah differencing musiman.

Menstasionerkan data yang tidak stasioner dalam varians dapat dilakukan dengan transformasi data sehingga didapatkan data yang stasioner dalam varians. Salah satu transformasi yang dapat digunakan adalah transformasi Box-Cox. Transformasi Box-Cox adalah transformasi pangkat pada respon dengan bentuk transformasi sebagai berikut [7]:

$$
T\left[Z_{t}\right]=Z_{t}^{\lambda}=\left\{\begin{array}{l}
\frac{Z_{t}^{\lambda}-1}{\lambda}, \lambda \neq 0 \\
\ln Z_{t}, \lambda=0
\end{array},\right.
$$

dengan lambda $(\lambda)$ merupakan nilai parameter transformasi dan $T\left(Z_{t}\right)$ merupakan fungsi transformasi terhadap $Z_{t}$.

\section{MODEL AUTOREGRESSIVE INTEGRATED MOVING AVERAGE (ARIMA)}

Model ARIMA $(p, d, q)$ merupakan gabungan model $\operatorname{AR}(p)$ dan $\operatorname{MA}(q)$ dengan pola data yang tidak stasioner dan dilakukan differencing orde $d$. Bentuk umum dari model ARIMA $(p, d, q)$ adalah sebagai berikut [5]: 


$$
\phi_{p}(B)(1-B)^{d} Z_{t}=\theta_{q}(B) a_{t}
$$

dengan

$\phi_{p}(B) \quad$ : koefisien komponen AR non musiman dengan orde $p$

$\theta_{q}(B) \quad$ : koefisien komponen MA non musiman dengan orde $q$

$(1-B)^{d} \quad$ : differencing non musiman dengan orde $d$

B : operator Backward shift

$a_{t} \quad$ : nilai error pada waktu ke- $t$.

MODEL SEASONAL AUTOREGRESSIVE INTEGRATED MOVING AVERAGE (SARIMA)

Generalisasi dari model ARIMA untuk data yang memiliki pola musiman, yaitu SARIMA $(p, d, q)(P, D, Q)^{S}$ dirumuskan sebagai berikut [5]:

$$
\phi_{p}(B) \Phi_{p}\left(B^{S}\right)(1-B)^{d}\left(1-B^{S}\right)^{D} Z_{t}=\theta_{q}(B) \Theta_{Q}\left(B^{S}\right) a_{t},
$$

dengan

$p, d, q \quad$ : orde AR, differencing, MA non musiman

$P, D, Q \quad$ : orde AR, differencing, MA musiman

$S \quad$ : musiman

$\Phi_{P}\left(B^{S}\right) \quad$ : koefisien komponen AR musiman $S$ dengan orde $P$

$\Theta_{Q}\left(B^{S}\right) \quad$ : koefisien komponen MA musiman $S$ dengan orde $Q$

$\left(1-B^{S}\right)^{D} \quad$ : differencing musiman $S$ dengan orde $D$

$a_{t} \quad$ : nilai error pada waktu ke-t.

\section{DOUBLE SEASONAL AUTOREGRESSIVE INTEGRATED MOVING AVERAGE (DSARIMA)}

Model DSARIMA merupakan model ARIMA yang mengandung pola dua musiman. Model DSARIMA $(p, d, q)\left(P_{1}, D_{1}, Q_{1}\right)^{S_{1}}\left(P_{2}, D_{2}, Q_{2}\right)^{S_{2}}$ dengan periode musiman pertama $\left(S_{1}\right)$ dan periode musiman kedua $\left(S_{2}\right)$. Orde dari musiman 1 autoregressive $\left(P_{1}\right)$, orde dari musiman 2 autoregressive ( $P_{2}$ ), orde dari musiman 1 moving average $\left(Q_{1}\right)$, orde dari musiman 2 moving average $\left(Q_{2}\right)$, orde dari musiman 1 differencing $\left(D_{1}\right)$ dan orde dari musiman 2 differencing $\left(D_{2}\right)$. Secara matematis, model DSARIMA dapat ditulis sebagai berikut [4]:

$$
\phi_{p}(B) \Phi_{P_{1}}\left(B^{s_{1}}\right) \Phi_{P_{2}}\left(B^{s_{2}}\right)(1-B)^{d}\left(1-B^{s_{1}}\right)^{D_{1}}\left(1-B^{s_{2}}\right)^{D_{2}} Z_{t}=\theta_{q}(B) \Theta_{Q_{1}}\left(B^{s_{1}}\right) \Theta_{Q_{2}}\left(B^{s_{2}}\right) a_{t},
$$

dengan

$\phi_{p}(B)=1-\phi_{1} B-\phi_{2} B^{2}-\ldots-\phi_{p} B^{p}$

$\theta_{q}(B)=1-\theta_{1} B-\theta_{2} B^{2}-\ldots-\theta_{q} B^{q}$

$\Phi_{P_{1}}\left(B^{s_{1}}\right)=1-\Phi_{11} B^{s_{1}}-\Phi_{12} B^{2 s_{1}}-\ldots-\Phi_{1 P_{1}} B^{P_{1} s_{1}}$

$\Phi_{P_{2}}\left(B^{s_{2}}\right)=1-\Phi_{21} B^{s_{1}}-\Phi_{22} B^{2 s_{2}}-\ldots-\Phi_{2 P_{2}} B^{P_{2} s_{2}}$

$\Theta_{Q_{1}}\left(B^{s_{1}}\right)=1-\Theta_{11} B^{s_{1}}-\Theta_{12} B^{2 s_{1}}-\ldots-\Theta_{1 Q_{1}} B^{Q_{1} s_{1}}$

$\Theta_{Q_{2}}\left(B^{s_{2}}\right)=1-\Theta_{21} B^{s_{1}}-\Theta_{22} B^{2 s_{2}}-\ldots-\Theta_{2 Q_{2}} B^{Q_{2} s_{2}}$.

\section{CONDITIONAL LEAST SQUARE (CLS)}

Salah satu cara untuk mengestimasi parameter model ARIMA adalah menggunakan metode Conditional Least Square. CLS adalah meminimumkan jumlah kuadrat error (SSE). Misalkan pada model AR(1) dinyatakan sebagai berikut [7],

$$
Z_{t}-\mu=\phi\left(Z_{t-1}-\mu\right)+a_{t}
$$


Pertama untuk mengestimasi parameter menggunakan metode CLS adalah mendapatkan fungsi conditional jumlah kuadrat error sebagai berikut,

$$
S_{c}\left(\mu, \phi_{1}\right)=\sum_{t=2}^{n} a_{t}^{2}=\sum_{t=2}^{n}\left[\left(Z_{t}-\mu\right)-\phi\left(Z_{t-1}-\mu\right)\right]^{2},
$$

kemudian diturunkan terhadap $\mu$ dan $\phi$ dan disamakan dengan nol sehingga diperoleh nilai taksiran parameter untuk $\mu$ sebagai berikut [7]:

$$
\hat{\mu}=\frac{\sum_{t=2}^{n} Z_{t}-\phi \sum_{t=2}^{n} Z_{t-1}}{(n-1)(1-\phi)},
$$

dan nilai taksiran parameter $\phi$ didapatkan sebagai berikut [7]:

$$
\hat{\phi}=\frac{\sum_{t=2}^{n}\left(Z_{t}-\bar{Z}\right)\left(Z_{t-1}-\bar{Z}\right)}{\sum_{t=2}^{n}\left(Z_{t-1}-\bar{Z}\right)^{2}} .
$$

\section{SUMBER DATA}

Data yang digunakan adalah data penggunaan beban listrik per jam di Kabupaten Natuna bulan Desember 2018. Jumlah data yang digunakan dalam penelitian ini adalah sebanyak 744 data yang dibagi menjadi data in sample dan out sample. Data in sample adalah data penggunaan beban listrik tanggal 1 Desember sampai 24 Desember 2018 sebanyak 576 data yang digunakan untuk membangun model, sedangkan data out sample adalah data penggunaan beban listrik tanggal 25 Desember sampai 31 Desember 2018 sebanyak 168 data yang digunakan untuk validasi model.

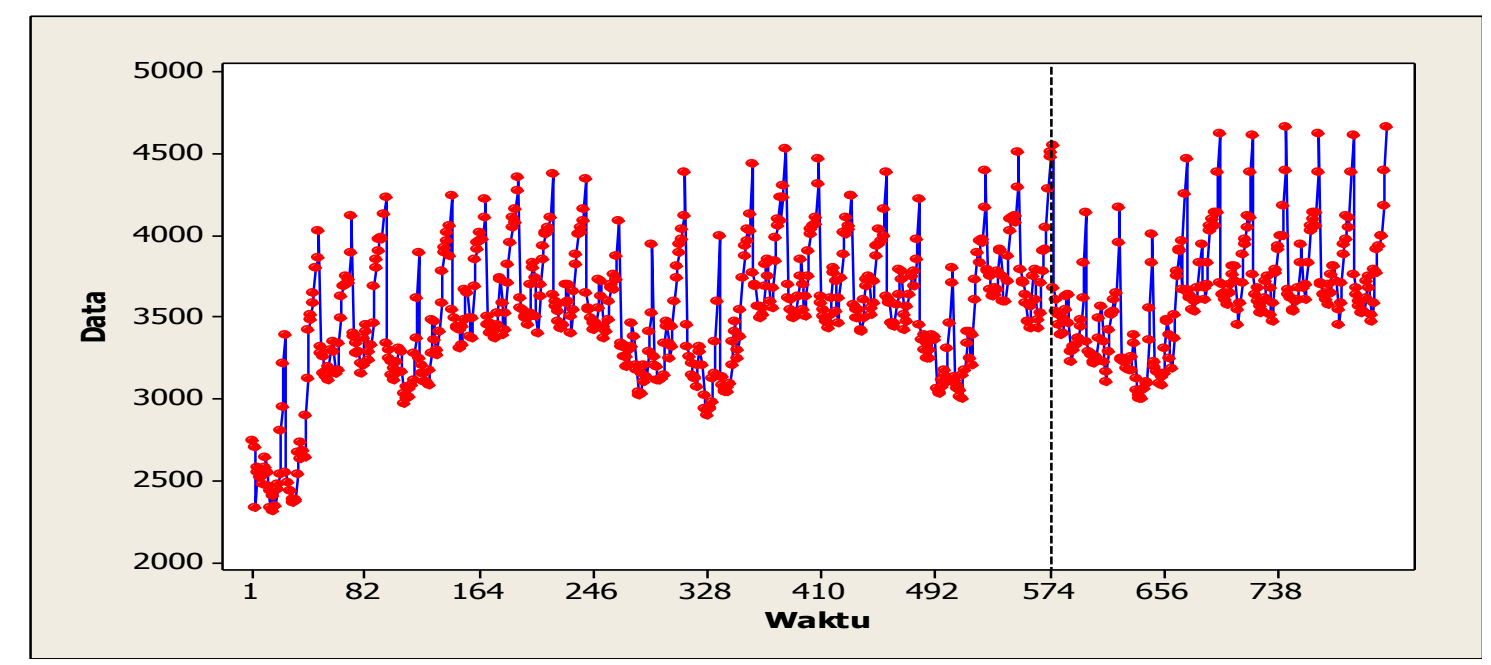

Gambar 1 Plot Data Penggunaan Beban Listrik

Gambar 1 menunjukkan pola pergerakan data penggunaan beban listrik dipengaruhi pola musiman yang menyebabkan data tidak stasioner dalam rata-rata dan varians. Data mengandung dua pola musiman yaitu musiman harian yang terjadi di setiap kelipatan 24 dan musiman mingguan yang terjadi pada setiap kelipatan 168 . Oleh sebab itu, metode yang digunakan dalam peramalan ini adalah metode DSARIMA.

\section{IDENTIFIKASI DATA}

Data deret waktu yang tidak stasioner dalam varians akan dilakukan transformasi menggunakan transformasi Box-Cox dengan melihat nilai Rounded Value atau $\lambda$ seperti terlihat pada Gambar 2. 


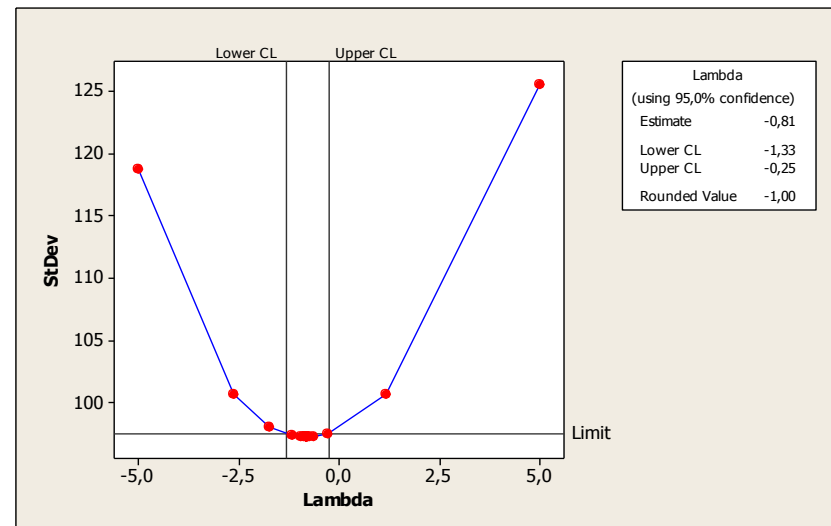

Gambar 2 Hasil Uji Box-Cox

Berdasarkan hasil uji Box-Cox pada Gambar 2 terlihat nilai Rounded Value atau $\lambda=-1,00$ kurang dari 1 yang menandakan bahwa data belum stasioner dalam varians. Transformasi yang sesuai untuk menstabilkan varians data tersebut adalah dengan transformasi Box-Cox $\frac{1}{z_{t}}$.

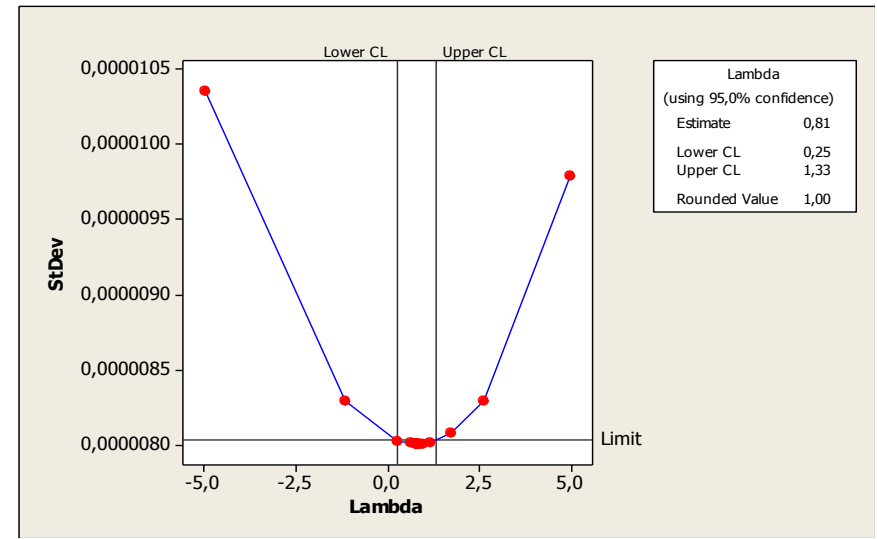

Gambar 3 Hasil Transformasi Box-Cox $\frac{1}{Z_{t}}$

Gambar 3 menunjukkan kondisi data setelah ditransformasi menggunakan transformasi $\frac{1}{z_{t}}$ dan diperoleh nilai $\lambda=1,00$, maka dapat dikatakan bahwa data sudah stasioner terhadap varians. Stasioneritas dalam rata-rata dapat diidentifikasi melalui plot ACF. Plot ACF yang memiliki pola turun sangat lambat mengindikasikan bahwa data tidak stasioner dalam rata-rata sehingga perlu dilakukan differencing.

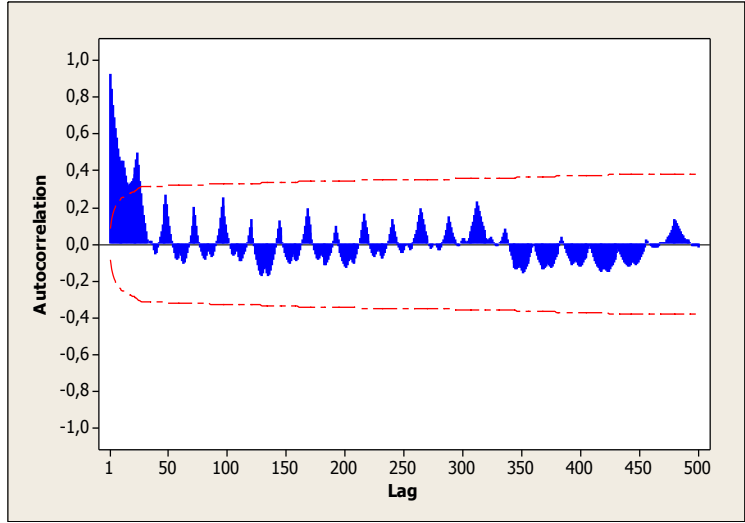

Gambar 4 Plot ACF Setelah Transformasi

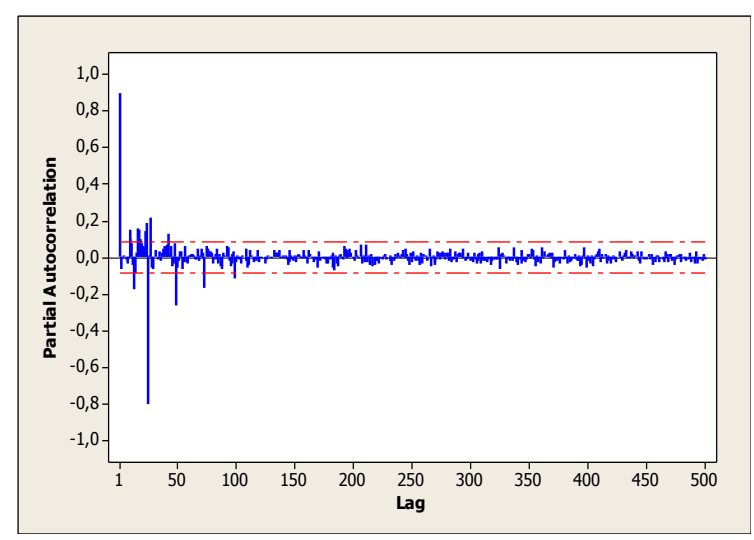

Gambar 5 Plot PACF Setelah Transformasi 
Dapat dilihat pada Gambar 4 bahwa nilai ACF lag pertama mendekati satu dan turun sangat lambat yang mengindikasikan bahwa data penggunaan beban listrik per jam tidak stasioner dalam rata-rata. Berdasarkan plot ACF, terlihat bahwa nilai ACF memiliki pola setiap kelipatan 168. Artinya, data penggunaan beban listrik per jam memiliki periode musiman mingguan atau per 168 jam. Plot PACF pada Gambar 5 terlihat bahwa PACF memiliki nilai yang signifikan pada kelipatan 24. Artinya, data beban listrik per jam memiliki periode musiman harian atau per 24 jam. Hal ini menunjukkan bahwa data penggunaan beban listrik memiliki dua pola musiman, maka akan dilakukan differencing terhadap pola musiman dan non musiman supaya data stasioner dalam rata-rata dan varians.

Data penggunaan beban listrik yang memiliki pola musiman harian dan mingguan selanjutnya dilakukan differencing dengan lag terkecil yakni 24 untuk musiman harian, lag 168 untuk musiman mingguan dan lag 1 untuk non musiman. Plot ACF dan PACF setelah dilakukan differencing lag 1, lag 24, dan lag 168 dapat dilihat pada Gambar 6 dan 7 yang mengindikasikan bahwa data telah stasioner.

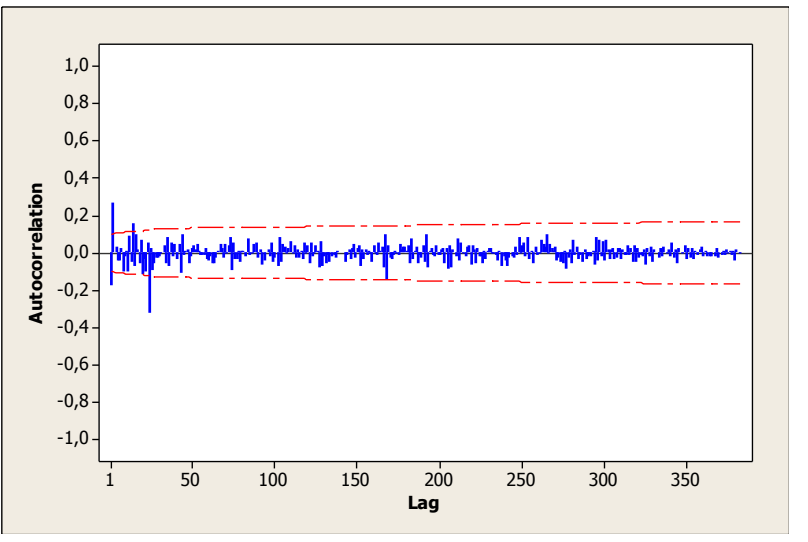

Gambar 6 Plot ACF Setelah Differencing

Lag 1, 24, dan 168

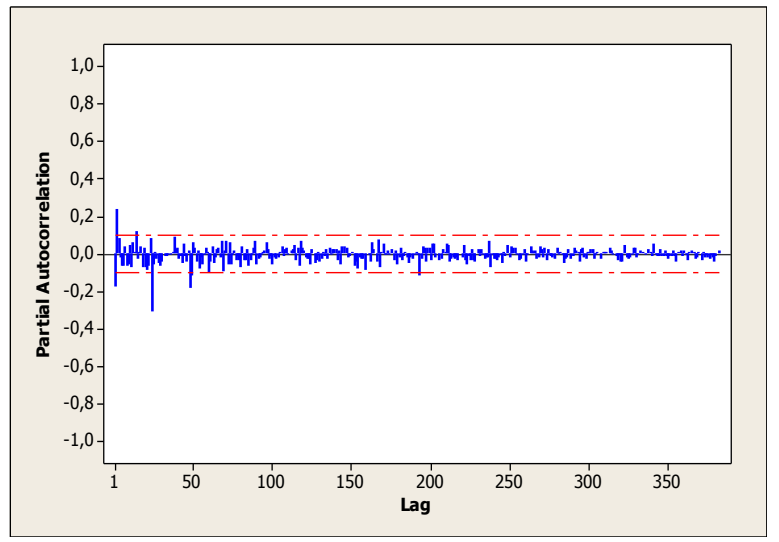

Gambar 7 Plot PACF Setelah Differencing

Lag 1, 24, dan 168

Berdasarkan Gambar 6 dapat dilihat bahwa data sudah stasioner setelah dilakukan differencing musiman pada lag 24 dan 168 serta non musiman pada lag 1. Plot data yang sudah stasioner dapat dilihat pada Gambar 8. Secara teoritis, plot ACF dan PACF dari data yang telah stasioner memiliki pola cut off. Berdasarkan plot ACF dan PACF dari data yang telah stasioner maka selanjutnya akan dilakukan identifikasi model.

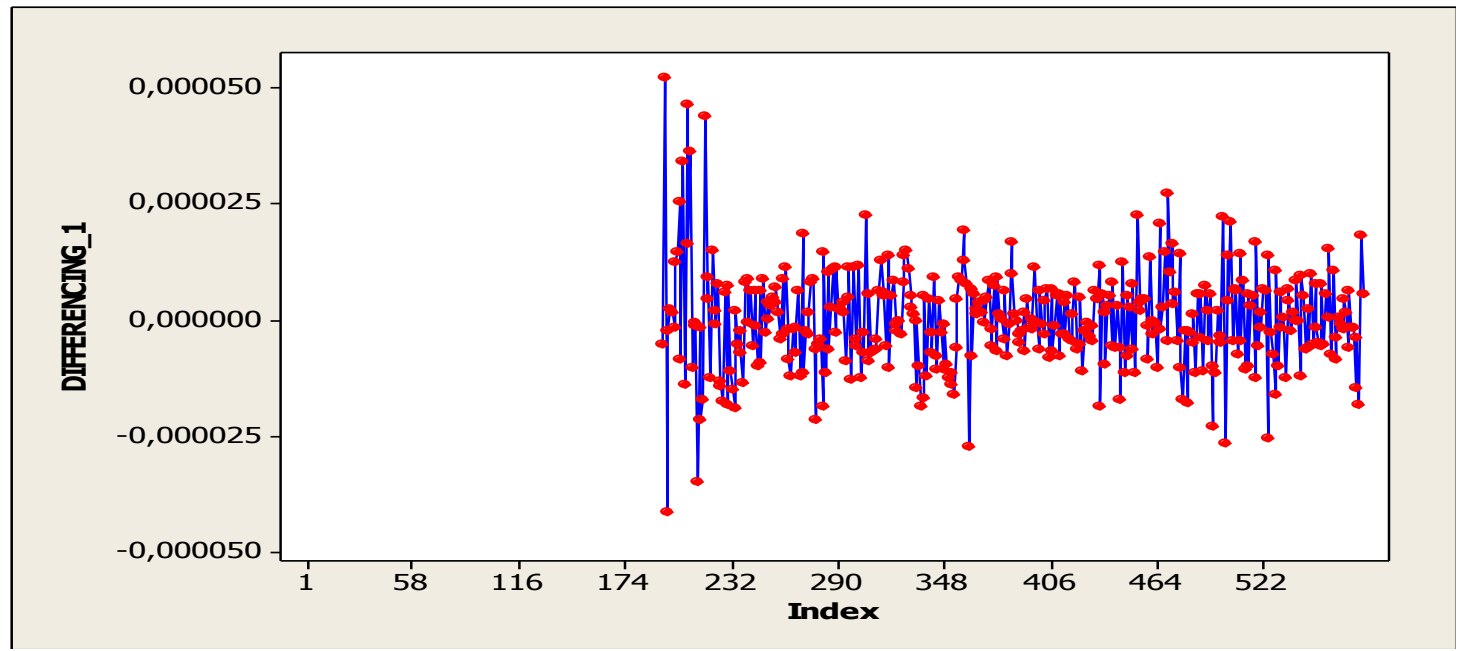

Gambar 8 Plot Data Setelah Dilakukan Differencing lag 1, 24, dan 168 


\section{IDENTIFIKASI MODEL}

Berdasarkan plot ACF dan PACF dari data yang telah stasioner, diperoleh 31 model dugaan. Dari 31 model dugaan akan dilakukan estimasi dan uji signifikansi parameter model dengan menggunakan metode Conditional Least Square (CLS).

\section{ESTIMASI DAN UJI SIGNIFIKANSI PARAMETER}

Estimasi model ini dilakukan untuk menguji apakah koefisien parameter signifikan atau tidak. Setelah dilakukan estimasi parameter dengan metode Conditional Least Square (CLS) diperoleh 3 model signifikan yaitu model DSARIMA([2], 1, [24] $)(0,1,0)^{24}(1,1,0)^{168}$, DSARIMA([2], 1, [24]) $(0,1,0)^{24}(0,1,1)^{168}$, dan $\operatorname{DSARIMA}(2,1,[24])(0,1,0)^{24}(0,1,0)^{168}$. Nilai estimasi parameter dari ketiga model DSARIMA dapat dilihat pada Tabel 1. Semua $p$-value bernilai kurang dari taraf signifikansi $\alpha=0,05$ menunjukkan bahwa semua parameter di setiap model telah signifikan.

Tabel 1 Nilai Estimasi Parameter Model DSARIMA

\begin{tabular}{|c|c|c|c|}
\hline \multirow{2}{*}{ Parameter } & \multicolumn{3}{|c|}{$\operatorname{DSARIMA}([2], 1,[24])(0,1,0)^{24}(1,1,0)^{168}$} \\
\hline & Estimate & $\mathbf{t}$ & p-value \\
\hline$\theta_{24}$ & 0,53496 & 11,97 & $<0,0001$ \\
\hline$\phi_{2}$ & 0,19842 & 3,91 & 0,0001 \\
\hline$\Phi_{21}$ & $-0,32221$ & $-4,96$ & $<0,0001$ \\
\hline \multirow{2}{*}{ Parameter } & \multicolumn{3}{|c|}{$\operatorname{DSARIMA}([2], 1,[24])(0,1,0)^{24}(0,1,1)^{168}$} \\
\hline & Estimate & $\mathbf{t}$ & p-value \\
\hline$\theta_{24}$ & 0,5364 & 11,97 & $<0,0001$ \\
\hline$\Theta_{21}$ & 0,27529 & 4,28 & $<0,0001$ \\
\hline$\phi_{2}$ & 0,19893 & 3,92 & 0,0001 \\
\hline \multirow{2}{*}{ Parameter } & \multicolumn{3}{|c|}{$\operatorname{DSARIMA}(2,1,[24])(0,1,0)^{24}(0,1,0)^{168}$} \\
\hline & Estimate & $\mathbf{t}$ & p-value \\
\hline$\theta_{24}$ & 0,54751 & 12,31 & $<0,0001$ \\
\hline$\phi_{1}$ & $-0,10607$ & $-2,11$ & 0,0358 \\
\hline$\phi_{2}$ & 0,19645 & 3,86 & 0,0001 \\
\hline
\end{tabular}

\section{UJI DIAGNOSTIK}

Pengujian dilakukan untuk mengetahui apakah residual telah memenuhi asumsi, baik white noise maupun berdistribusi normal. Pengujian asumsi white noise dilakukan dengan Uji Ljung-Box sedangkan pengujian asumsi distribusi normal dilakukan dengan menggunakan uji KolmogorovSmirnov. Berikut adalah tabel hasil uji Ljung-Box dan uji Kolmogorov-Smirnov.

Tabel 2 Uji Asumsi Residual Model DSARIMA

\begin{tabular}{lccccc}
\hline Model & \multicolumn{3}{c}{ Uji Ljung-Box } & \multicolumn{2}{c}{ Uji Kolmogorov-Smirnov } \\
& Lag & $\boldsymbol{Q}$ & $\boldsymbol{p}$-value & $\mathbf{D}$ & $\boldsymbol{p}$-value \\
\hline DSARIMA([2], 1, [24] $(0,1,0)^{24}(1,1,0)^{168}$ & 48 & 41,77 & 0,6094 & 0,035665 & 0,15 \\
DSARIMA([2], 1, [24]) $(0,1,0)^{24}(0,1,1)^{168}$ & 48 & 40,79 & 0,6508 & 0,035263 & 0,15 \\
DSARIMA(2, 1, [24] $(0,1,0)^{24}(0,1,0)^{168}$ & 48 & 38,83 & 0,7295 & 0,041178 & 0,1133 \\
\hline
\end{tabular}


Pada Tabel 2 dapat dilihat bahwa nilai p-value uji Ljung-Box bernilai lebih dari taraf signifikan 0,05 sehingga dapat disimpulkan bahwa ketiga model memiliki residual yang white noise atau bersifat random masing-masing hingga lag 48. Sedangkan p-value uji Kolmogorov-Smirnov untuk ketiga model bernilai lebih dari taraf signifikan 0,05. Artinya, residual ketiga model berdistribusi normal.

\section{VERIFIKASI MODEL}

Berdasarkan Tabel 1 dan Tabel 2 ketiga model DSARIMA memiliki parameter signifikan serta residual white noise dan berdistribusi normal, selanjutnya digunakan untuk meramal hingga 168 tahap ke depan untuk periode 25 hingga 31 Desember 2018. Hasil ramalan yang diperoleh akan dibandingkan dengan data out sample sehingga diperoleh MAPE out sample sebagai berikut.

Tabel 3 MAPE Out-Sample Model DSARIMA

\begin{tabular}{cc}
\hline Model & $\begin{array}{c}\text { MAPE Out } \\
\text { Sample }\end{array}$ \\
\hline DSARIMA([2], 1, [24]) $(0,1,0)^{24}(1,1,0)^{168}$ & 0,111 \\
DSARIMA $([2], 1,[24])(0,1,0)^{24}(0,1,1)^{168}$ & 0,108 \\
DSARIMA $(2,1,[24])(0,1,0)^{24}(0,1,0)^{168}$ & $\mathbf{0 , 0 8 9}$ \\
\hline
\end{tabular}

Berdasarkan Tabel 3 model DSARIMA $(2,1$, [24] $)(0,1,0)^{24}(0,1,0)^{168}$ memiliki nilai MAPE out sample terkecil sehingga model tersebut merupakan model terbaik yang dapat digunakan dalam meramal data penggunaan beban listrik di Kabupaten Natuna. Secara matematis model DSARIMA(2, 1, [24]) $(0,1,0)^{24}(0,1,0)^{168}$ dapat ditulis sebagai berikut:

$$
\begin{aligned}
\hat{Z}_{t}= & 0,89393 Z_{t-1}+0,30252 Z_{t-2}-0,19645 Z_{t-3}+Z_{t-24}-0,89393 Z_{t-25}-0,30252 Z_{t-26}+0,19645 Z_{t-27} \\
& +Z_{t-168}-0,89393 Z_{t-169}-0,30252 Z_{t-170}+0,19645 Z_{t-171}-Z_{t-192}+0,89393 Z_{t-193}+0,30252 Z_{t-194} \\
& -0,19645 Z_{t-195}-0,54751 a_{t-24}+a_{t}
\end{aligned}
$$

Selanjutnya adalah membandingkan hasil peramalan dengan data out Sample. Gambar 9 menunjukkan bahwa grafik hasil peramalan hampir mendekati grafik data aktual. Artinya, model $\operatorname{DSARIMA}(2,1,[24])(0,1,0)^{24}(0,1,0)^{168}$ merupakan model terbaik yang dapat digunakan dalam meramal penggunaan beban listrik di Kabupaten Natuna untuk periode 25 sampai 31 Desember 2018 atau 168 jam kedepan.

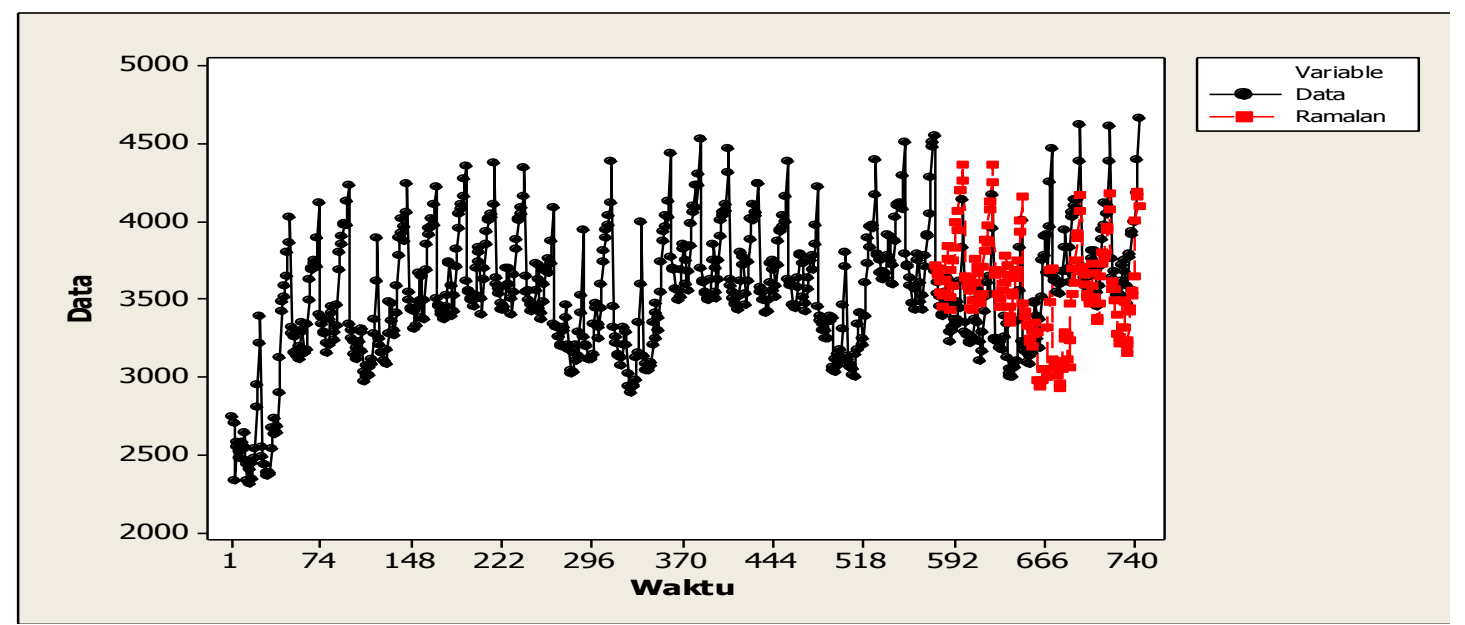

Gambar 9 Grafik Perbandingan Hasil Peramalan 


\section{PERAMALAN}

Model DSARIMA(2, 1, [24] $)(0,1,0)^{24}(0,1,0)^{168}$ dapat digunakan untuk meramalkan data penggunaan beban listrik di Kabupaten Natuna. Hasil peramalan penggunaan beban listrik untuk periode 25 Desember sampai 31 Desember 2018 dapat dilihat pada Gambar 9. Berdasarkan Gambar 9 hasil ramalan untuk 168 tahap kedepan menunjukkan bahwa penggunaan beban listrik tertinggi terjadi pada periode 48 tanggal 26 Desember pukul $23.00 \mathrm{WIB}$ sebesar 4363,38 kWh. Artinya, penggunaan beban listrik paling banyak digunakan pada malam hari. Penggunaan beban listrik terendah terjadi pada periode 103 tanggal 29 Desember pukul 06.00 WIB sebesar 3132,154 kWh. Artinya, penggunaan beban listrik pada pagi hari lebih rendah dari pada malam hari.

\section{KESIMPULAN}

1. Model terbaik yang dapat digunakan dalam peramalan penggunaan beban listrik di Kabupaten Natuna adalah model DSARIMA(2, 1, [24]) $(0,1,0)^{24}(0,1,0)^{168}$, dengan MAPE out sample terkecil yaitu 0,089 atau 8,9\%. Bentuk persamaan dari model dapat ditulis sebagai berikut.

$$
\begin{aligned}
\hat{Z}_{t}= & 0,89393 Z_{t-1}+0,30252 Z_{t-2}-0,19645 Z_{t-3}+Z_{t-24}-0,89393 Z_{t-25}-0,30252 Z_{t-26}+0,19645 Z_{t-27} \\
& +Z_{t-168}-0,89393 Z_{t-169}-0,30252 Z_{t-170}+0,19645 Z_{t-171}-Z_{t-192}+0,89393 Z_{t-193}+0,30252 Z_{t-194} \\
& -0,19645 Z_{t-195}-0,54751 a_{t-24}+a_{t}
\end{aligned}
$$

2. Hasil peramalan penggunaan beban listrik untuk periode 25 Desember pukul 00.00 WIB hingga 31 Desember pukul 23.00 WIB, menujukkan bahwa penggunaan beban listrik terendah terjadi di pagi hari saat sebagian besar konsumen mematikan peralatan elektronik rumah tangga. Penggunaan beban listrik tertinggi terjadi pada malam hari saat sebagian besar konsumen perlu mengoperasikan banyak peralatan setelah pulang kerja.

\section{DAFTAR PUSTAKA}

[1]. Kuncoro, M. dan Inayah, H. Adakah Pengaruh Pernyataan Presiden Gus Dur Terhadap Perilaku Kurs Rp/US\$, 1 Januari 1999-30 April 2002. Jurnal Ekonomi dan Bisnis Indonesia, 18(4):341-360; 2003.

[2]. Suhartono dan Endharta, A.J. Peramalan Konsumsi Listrik Jangka Pendek dengan Arima Musiman Ganda dan Elman-Recurrent Neural Network. Jurnal Teknologi Informasi, 7(4):183190; 2009.

[3]. Saptyani, M., Sulandari, W., dan Pangadi. Peramalan Penggunaan Beban Listrik Jangka Pendek Gardu Induk Bawen dengan DSARIMA. Media Statistika, 8(1):41-48; 2015.

[4]. Chrisdayanti, B. dan Suharsono, A. Peramalan Kandungan Particulate Matter (PM10) dalam Udara Ambien Kota Surabaya Menggunakan Double Seasonal ARIMA (DSARIMA). Sains Dan Seni ITS, 4(2):242-247; 2015.

[5]. Wei, W. W. S. Time Series Analysis: Univariate and Multivariate Methods Second Edition. New York: Addison Wesley;2006.

[6]. Makridakis, S., Wheelwright, S. C., dan McGee, V. E. Metode dan Aplikasi Peramalan. Jakarta: Bina Rupa Aksara;1999.

[7]. Cryer, J.D \& Chan, K.S. Time Series Analysis with Applications in R Second Edition. New York: Springer Science-Business Media, LLC; 2008. 
SUAIBAH

SHANTIKA MARTHA

DADAN KUSNANDAR
: Jurusan Matematika FMIPA UNTAN, Pontianak su_aibah@student.untan.ac.id

: Jurusan Matematika FMIPA UNTAN, Pontianak shantika.martha@math.untan.ac.id

: Jurusan Matematika FMIPA UNTAN, Pontianak dkusnand@untan.ac.id 